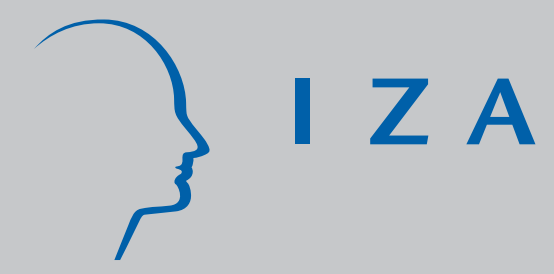

IZA DP No. 3404

Individual Incentives in Program Participation:

Splitting up the Process in Assignment and Enrollment

Andrea Weber

March 2008 


\title{
Individual Incentives in Program Participation: Splitting up the Process in Assignment and Enrollment
}

\author{
Andrea Weber \\ RWI Essen, UC Berkeley, \\ IHS Vienna, CESifo and IZA
}

\author{
Discussion Paper No. 3404 \\ March 2008
}

\author{
IZA \\ P.O. Box 7240 \\ 53072 Bonn \\ Germany \\ Phone: +49-228-3894-0 \\ Fax: +49-228-3894-180 \\ E-mail: iza@iza.org
}

\begin{abstract}
Any opinions expressed here are those of the author(s) and not those of IZA. Research published in this series may include views on policy, but the institute itself takes no institutional policy positions.

The Institute for the Study of Labor (IZA) in Bonn is a local and virtual international research center and a place of communication between science, politics and business. IZA is an independent nonprofit organization supported by Deutsche Post World Net. The center is associated with the University of Bonn and offers a stimulating research environment through its international network, workshops and conferences, data service, project support, research visits and doctoral program. IZA engages in (i) original and internationally competitive research in all fields of labor economics, (ii) development of policy concepts, and (iii) dissemination of research results and concepts to the interested public.
\end{abstract}

IZA Discussion Papers often represent preliminary work and are circulated to encourage discussion. Citation of such a paper should account for its provisional character. A revised version may be available directly from the author. 


\section{ABSTRACT \\ Individual Incentives in Program Participation: Splitting up the Process in Assignment and Enrollment}

In this paper we investigate two stages in the process that leads to participation in ALMP programs. We use unique administrative data from the Austrian unemployment registers which allow us to distinguish between caseworker assignment and actual program enrollment. Although $25 \%$ of newly unemployed workers are assigned to a program, only half of them enroll and participate in the program longer than 5 days. This difference between assignment and enrollment rates cannot be explained by job entries, program cancelations, or rejected program applications alone. Therefore we analyze the influence of observable characteristics on each stage of the participation process. We find that beside policy regulations individual worker incentives play an important role in determining program participation.

JEL Classification: J24, J68

Keywords: unemployment, active labor market policy, evaluation

Corresponding author:

Andrea Weber

UC Berkeley

549 Evans Hall \#3880

Berkeley, CA 94720-3880

USA

E-mail: webera@econ.berkeley.edu

\footnotetext{
* Financial support for this research was provided by the Austrian National Bank, Jubilaeumsfonds grant no. 10823. All errors and opinions are the author's sole responsibility.
} 


\section{Introduction}

In the literature on empirical evaluation of social programs the problem of nonrandom selection of participants has a central role. Yet, detailed information on the participation process is rarely available and so the underlying identification assumptions remain largely un-testable. In this paper we use unique data that provide information on assignments as well as enrollments into programs of active labor market policy (ALMP) in Austria. This allows us to decompose the participation process in two separate stages: the assignment stage where the unemployed worker receives notice of an open program slot, and the enrollment stage which starts when the worker actually enrolls and participates in the assigned program. We use the analytical framework developed by Heckman and Smith (2004) to separately analyze the empirical determinants at each stage of the participation process.

A detailed analysis of the participation process in is important for several reasons. First and most general, it provides insights on inequalities in the allocation of public benefits, which might not only depend on eligibility rules but also on differential access and take-up across the population (Currie, 2006). Our approach allows us not only to compare participation rates of different demographic groups but also to analyze at which stage in the process the differences occur.

Second, a common finding in empirical evaluation studies is that program effects are heterogeneous and that ALMP programs are only beneficial for certain groups. For the policy maker it is thus important to efficiently allocate unemployed workers to programs and the individual worker to the right type of program. An approach to investigate the efficiency of program allocations is to compare caseworker assignments with more refined statistical assignment mechanisms (Behncke et al., 2007; Dehejia, 2005; Lechner and Smith, 2007; Staghoj et al., 2007). However, in these studies it is usually assumed that the official 
assignment is binding, which means that policy rules can be enforced and that the individual workers do not influence the participation decision. By using more detailed data and splitting up the participation process we can examine to what extent workers interfere in the participation process or do not comply with the official assignment.

Third, a closer examination of the participation process can also be helpful in the choice of evaluation strategies (Heckman et al., 1999). Here, a broad distinction between empirical approaches can be made regarding the assumptions about the observability of factors determining selection. On the one hand, matching and propensity score methods are based on the "selection on observables" assumption, which implies that the researcher is able to observe all information that determines program participation and also influences the outcomes (Dehejia and Whaba, 1999; Heckman and Smith, 1999). The argument usually made in favor of this assumption is that with the availability of longitudinal administrative data the researcher observes roughly the same information as the caseworker, and is hence able to model the caseworker's decision. This should be the case if the participation decision depends exclusively on the caseworker. If, on the other hand, the individual worker is able to influence the participation process, "selection on observables" is less credible. The individual might have important private information that determines both participation and labor market outcomes, but is not shared with either the caseworker or the researcher. In this case we have "selection on unobservables" and an evaluation strategy that relies on an exogenous exclusion restrictions by, for example, making use of particularities of the participation process may be more appropriate (Angrist et al., 1996; Heckman, 1997).

In this paper we follow new entrants into unemployment over their unemployment spell and record all program assignments and enrollments. We find that while almost $25 \%$ of unemployed are assigned to a program relatively early in their unemployment spells only $12 \%$ enroll. To explain this attrition we exam- 
ine job entries, program cancelations, and rejections of program applications. Further we investigate the empirical determinants of the probabilities to be assigned and to be enrolled conditional on assignment. Our analysis provides strong evidence in favor of the individual worker's influence over the participation process.

The rest of the paper is organized as follows. The next section gives a brief overview of active labor market policy in Austria and the different program types available. Section 3 describes the data and provides summary statistics on program assignments and enrollments. Section 4 discusses incentives involved at each stage of the participation process and examines in detail the empirical determinants at both stages. The last section concludes.

\section{Active Labor Market Policy in Austria}

In Austria like in many other European countries, the active component of labor market policy has increased in importance over the last 2 decades, with government spending on ALMP now amounting to about $0.6 \%$ of GDP (OECD, 2007). A major change in the types of policies offered and subsequently in participation rates occurred during 1999/2000, when job search programs where introduced on a relatively large scale (Hofer and Weber, 2006). These programs, designed to improve search efficiency, were meant to complement existing training and employment subsidy programs that are oriented toward human capital improvements. Further, the intention of job search programs was to reach out to unemployed workers in early stages of unemployment, to make them familiar with the ALMP programs offered, to develop structured training plans, and to provide a better screening device for the more costly training programs (Arbeitsmarktservice Österreich, 2001).

The access to active labor market programs is provided exclusively by regional employment offices, while the courses are held by private contractors. In gen- 
eral, the Austrian employment office (AMS) provides counseling and job placement for unemployed workers, and it administers unemployment insurance benefits and ALMP. A worker requesting services can approach the office by registering as unemployed or searching for a job, and claim benefit payments if eligible. A registered worker attends regular meetings with caseworkers, where job offers, job search strategies, and available ALMP options are discussed. In order to get assigned to a program the worker can either submit an application through the caseworker or she is directly assigned by the caseworker. During the period following assignment the application is reviewed and the worker waits for the start of the program. If the application is accepted and if the worker is still unemployed at the program start they formally enroll and participate in the program.

In this paper we use administrative data on individual assignments and enrollments to training, job search, and public sector employment programs that were administered by the employment office. We do not consider private sector employment subsidies, because they follow a different system. Private employment programs are wage subsidies paid to the employer for hiring an eligible worker. Vacancies for employment subsidies get posted at the employment office and workers apply for those like for regular jobs. Therefore there is no formal assignment procedure as in the case of the course-related program types. ${ }^{1}$

\section{Data}

Our data come from two sources: the Austrian Social Security Database (ASSD) and the unemployment registers of the Austrian public employment office (AMS). We use detailed information on employment, unemployment, and wages from daily records in the ASSD, which are available for the years 1972-2004. Two

\footnotetext{
${ }^{1}$ Compared to other European countries, private sector employment subsidies play a minor role in the Austrian ALMP system (Hofer and Weber, 2006).
} 
separate databases from the unemployment registers provide information on program assignments and enrollment. The assignment data include the date of assignment, a program number, the planned starting date of the program, and the result from assignment (participation or non-participation plus the reason why no participation occurred). The enrollment data include the program number, as well as dates of entry into and exit from the program.

Our observation sample consists of the inflow into unemployment between March and August 2001. We define an individual's inflow into unemployment by the start of her first unemployment spell. We restrict unemployment spells to be longer than one day. Further, we restrict individuals to be between 16 and 60 years of age and we drop individuals who were unemployed within 30 days prior to the start of the inflow spell. From the enrollment data we select all programs, which start during the first year of the unemployment spell or before the individual enters a new job. We only consider an individual as enrolled if she participates in a program for more than 5 consecutive days. For individuals who are enrolled in multiple programs we select the program that starts first. The program number gives us access to additional information about the program like program type and the total number of participants. Our analysis distinguishes between training, job search, and public employment programs. ${ }^{2}$ In the ASSD we can define unemployment by either benefit recipience or registration with the unemployment office. We allow for unemployment spells of either status, but for defining the inflow date into unemployment the spell can only start after the individual has exited employment. To get an accurate record of program assignments, however, we take into account that workers anticipating unemployment may actually register with the employment office before their job has ended. We call workers who register as searching for a new job while still employed "early searchers" and consider all program assignments

\footnotetext{
${ }^{2}$ This means we drop all individuals receiving start up grants (UGP) or Arbeitsstiftungen. Participations in BBE (Beratungs- und Betreuungseinrichtungen) are excluded, because they last only for one day.
} 
from the assignment database which take place from the first contact to the employment office preceding the inflow into unemployment. Using these definitions we are able to match $99 \%$ of enrollments in the enrollment database with a corresponding assignment from the assignment database. Cross-checking the information on the result of program assignment in the assignment database with the the actual enrollment gives a perfect overlap.

The full sample includes 226,621 individuals and; their descriptive characteristics are shown in table 1. Information on program assignments and enrollments are given in table 2 . We see that $25 \%$ of workers are assigned to a program at least once during their unemployment spell, while only $12 \%$ enroll in at least one program. It is not uncommon that workers are assigned to programs multiple times. Workers who are assigned receive on average 1.7 assignments, and workers who enroll got on average 2 assignments. Enrollment in more than one program is not so common as we only consider the first 12 months after inflow into unemployment.

Table 3 provides some information about the timing of program assignment and enrollment during the unemployment spell. It takes the average worker 151 days to find a new job, the median nonemployment duration is about 3 months. (Note that spells are censored at 365 days.) Workers who are assigned to at least one program are out of employment much longer than the average worker. The median worker with assignment takes almost 10 months to find a job, although the assignment already occurs in the second month of unemployment. The median time from assignment to the projected program start is 3 weeks. It is clear that workers enrolling in a program take longer to start with a new job, because of the time they spend on the program, which is 44 days for the median worker. The median enrolled worker gets her first assignment in the second month of unemployment, but does not enroll in a program until about 2 months later. 
In this context is interesting to see whether assigned individuals do not enroll in the program, because they find a job before the program starts. Only $13 \%$ of assigned workers enter employment before the planned program start. We have seen in table 2, however, that it is not uncommon, that workers who do not enroll in the first program get re-assigned to a different program with a later starting date. Therefore we also consider all individuals who start a job within 2 months of the first assignment date. With this measure the rate of job entry after assignment is $28 \%$, but it is still lower than the enrollment rate of $50 \%$ among assigned workers.

Table 4 gives an overview of the results from the first program assignment. We see that only $30 \%$ of individuals participate in the first program they are assigned to. As mentioned above, $13 \%$ take up a job before the program would have started. The rate of individual rejections to enroll in the program is particularly high with $30 \%$, while rejections of program applications by the employment office are less common with $7 \%$. Finally, the remaining $20 \%$ do not enroll, because the their program is canceled by the unemployment office, maybe because of a too low number of participants. ${ }^{3}$

Program types of the first assignment and enrollment per individual are given in table 5. The majority of both assignments and enrollments are to job search programs. The second important category are training programs. Orientation programs, a sub-category of training, which support unemployed workers to get organized and to develop training and career plans, and public sector employment programs are less used. The enrollment rates (number of enrollments over number of assignments) are higher to training programs with $77 \%$ than to job search programs with $61 \%$. We further note that for a large share $(28 \%)$ of assignments the program type is unspecified. The majority $(84 \%)$ of the unspecified programs are canceled, because they have no enrolled participants.

\footnotetext{
${ }^{3}$ We identify canceled programs by program numbers with zero enrolled participants in the data.
} 
We would like to point out that the descriptive statistic based on the mean or median workers as presented above may hide some underlying patterns. Figure 1 shows the distribution of the time from the start of the unemployment spell to first program assignment for all workers who were assigned to a program in the first year of unemployment. The huge spike in the graph at time zero reflects that $20 \%$ of assigned workers ( $5 \%$ of the full sample) receive an assignment already on the first day when they register with the employment office. Reasons for these direct assignments seem to be incompatibilities between the numbers of caseloads and slots for caseworker meetings. Schernhammer and Adam (2002) discuss that in 2000 the official guidelines recommended that program participation in job search programs should be preceded by a series of monthly meetings with the caseworker where the worker is informed about the program and invited to participate. In several employment offices, however, the density of caseloads did not permit to schedule the required number of meetings. According to the report local employment offices sought different ways out of these incompatibilities and thus some offices made assignments already on the first contact day, while others postponed the assignment to a later date. ${ }^{4}$

\section{Stages in the Program Participation Process}

The descriptive analysis in the last section makes clear that beside rejected applications, job entries, or program cancelations also individual rejections play a considerable role in explaining the difference between assignment and enrollment rates in the data. In addition, we found that repeated program assignments are relatively common and many workers receive multiple assignments before they enroll in the first program. This indicates that individual workers are strongly involved in the participation process and seem to have some leverage in negotiations with caseworkers. Therefore, our next step is to ana-

\footnotetext{
${ }^{4}$ For further details see (Weber, 2008).
} 
lyze the influence of individual characteristics at each stage of the participation process. This will allow to distinguish between government rules regulating program access and caseworker incentives on the one hand, and individual worker incentives on the other hand.

Before going into details about empirical findings we start with a discussion about the incentives of the different parties involved in the decision making at each stage of the participation process. The caseworker assigning an unemployed to a program follows government eligibility regulations and policy guidelines as well as strategies outlined at the local employment office. In addition, he forms his own private assessment from personal contact with the client. The worker can influence the assignment decision by approaching the caseworker with the explicit wish to apply for a certain program. In such cases the final application will still be guided by caseworker recommendations, however.

At the enrollment stage the probability to enroll conditional on assignment is influenced by three main factors. First, the unemployment office is involved by accepting or rejecting the worker's application. In case of a rejection, the worker may re-apply or be re-assigned to a different course though. Second, we have seen that some programs are canceled, presumably because of low enrollment rates. We argue that program cancelations can be regarded as a random component in the enrollment process, because they do not depend on the individual worker. Third, the worker has several means to influence the likelihood of enrollment. She can manipulate the job entry by either taking a job quickly or delaying entry into employment until after the program. ${ }^{5}$ Further, the worker can reject program enrollment. Although most programs are compulsory and non-compliance may result in benefit sanctions, the worker can find excuses or at least negotiate a later program entry with the caseworker.

Overall, the discussion suggests that the assignment stage the decision is likely

\footnotetext{
${ }^{5}$ For an investigation of the effect of program assignment on job entry rates see (Weber, 2008).
} 
to be dominated by policy regulations and employment office strategies, while at the enrollment stage the individual worker's incentives play a more dominant role. Examining the effects of observable factors on the assignment and enrollment probabilities separately will reveal to what extent official policies are reinforced or counteracted by individual incentives.

To examine the effect of various observable characteristics on each stage of the participation process we decompose the probability to participate $\operatorname{Pr}($ par $=$ $1 \mid x)$ given a set observable characteristics $x$ into the probability to be assigned $\operatorname{Pr}(a s=1 \mid x)$ and the probability to enroll conditional on assignment $\operatorname{Pr}(e n=$ $1 \mid$ as $=1, x)$ by

$$
\operatorname{Pr}(\operatorname{par}=1 \mid x)=\operatorname{Pr}(e n=1 \mid a s=1, x) \operatorname{Pr}(a s=1 \mid x) .
$$

We then estimate simple logit models for the probabilities to enter both stages. Estimation results are presented in Table 6. The first column shows determinants of program assignment, while the third column shows the determinants of enrollment conditional on assignment. A first inspection of the results makes clear that individual characteristics are strongly influencing the process at both stages and often with offsetting effects. ${ }^{6}$ The coefficient estimates on regional dummy variables indicate considerable variation in assignment strategies as well as supply of ALMP programs at the regional level. We also estimated models controlling for fixed effects at the local employment office level which demonstrate this even more convincingly. ${ }^{7}$

To focus on the magnitude of the effects, we decompose the overall effect of variable $x_{j}$ on program participation into the effect due to assignment and due to enrollment

$$
\frac{\partial \operatorname{Pr}(\text { par }=1 \mid x)}{\partial x_{j}}=\frac{\partial \operatorname{Pr}(\text { en }=1 \mid a s=1, x)}{\partial x_{j}} \operatorname{Pr}(a s=1 \mid x)
$$

\footnotetext{
${ }^{6}$ Results estimated for women and men separately are shown in tables 8 and 9 .

${ }^{7}$ Results from a model with 94 local employment office dummies are available on request.
} 


$$
+\operatorname{Pr}(e n=1 \mid a s=1, x) \frac{\partial \operatorname{Pr}(a s=1 \mid x)}{\partial x_{j}}
$$

The first column in table 7 gives the overall effect on participation or the term on the right hand side of equation (2). Because of the nonlinearity of the logit model all effects are evaluated for a worker with the median values of $x$ characteristics. In the second and fifth columns we present the marginal effects from the logit models on the probabilities of assignment and enrollment, respectively. In case of indicator variables the discrete change reported. The decomposition into the two summands on the left hand side of equation (2) are given by the product of the marginal effects and the probabilities that the median $x$ worker is assigned $\operatorname{Pr}(a s=1 \mid x)=0.17$ or enrolled conditional on assignment $\operatorname{Pr}($ en $=1 \mid a s=1, x)=0.52$. In columns four and seven we express those terms as percentages of the overall effect. Comparing the percentage contributions from both stages it is apparent that most variables have a stronger influence at the enrollment stage.

Now let us turn to the estimation results. Everything else equal female workers are more likely to be assigned to programs, but conditional on being assigned females are also more likely to enroll than males. The effect of gender is even stronger on the enrollment component than on assignment. We find the same directions of effects for older workers and married workers. Both characteristics lead to a slightly higher probability of assignment but to a decidedly higher likelihood to enroll once assigned.

In the case of educational groups individual and policy incentives seem to counteract. Although the least educated workers seem to be a specific target group of ALMP and thus most likely to be assigned to programs, they have lower enrollment rates conditional on assignment than workers holding apprenticeships or middle- and high school graduates.

Temporary layoffs play a big role in the Austrian labor market, which is highly 
seasonal. We cannot directly control for temporary layoff status, but we use the fact that the worker is recalled to the previous employer as a proxy. As we can see being on recall has a strongly negative influence on the probability of being assigned. This is because the caseworkers keep track of recall agreements with employers and lower the level of counseling for temporary layoffs. But also workers who plan to return to their previous employer have lower enrollment rates once they get assigned. We see the same pattern for occupations in the seasonal industries like tourism and construction, where most of the temporary layoffs occur. A higher probability to be assigned is faced by individuals working in manufacturing, sales, office, and technical occupations. These workers are also more likely to enroll.

Benefit recipients are more likely to be assigned to programs and they are also more likely to enroll once they get assigned. This could be, because they face pressure from benefit sanctions or because program applications of non-benefit recipients who are not a primary policy target group are more likely to be rejected. Workers who enter unemployment from out of the labor force are less likely to get assigned to programs but conditional on assignment they have higher attendance rates. This indicates that in the case of individuals who register with AMS to become eligible for ALMP programs to some extent also the decision to be assigned might be driven by individual incentives. Another group of workers who might be highly motivated to participate in programs are those who register early with AMS before their job ends. For these workers we see particularly high enrollment rates conditional on assignment.

Past program participation could indicate that workers are on some kind of training schedule which continues when they re-enter unemployment. We find that program participation in the 18 months before getting unemployed is a strong indicator for assignment and that enrollment conditional on assignment is also higher for individuals with recent program experience. 
Labor market histories, and especially the unemployment experience in recent years are important determinants of program participation. While the time spent in unemployment in the past years increases the probabilities to be assigned and to enroll in a program, a higher number of unemployment spells lowers the probability to be assigned but still increases the conditional enrollment probability. Repeated employment spells have negative effects on both probabilities, which indicates that workers who have more contacts in the labor market are less dependent on the public services. Results on pre-unemployment wages seem to resemble the finding for educational groups: namely, although low wage workers are more likely to be assigned, higher wages positively influence the conditional enrollment rates.

We find differential patterns on assignment and enrollment probabilities by the month of inflow into unemployment and by region. Here it is interesting that in regions where assignment probabilities are high, like in Vienna and most Eastern Austrian regions, enrollment rates are considerably lower. This hints at differential assignment strategies at the local employment office level.

\section{Conclusion}

The objective of this article was to investigate two stages in the process that leads to participation in ALMP programs using special Austrian data that allow us to distinguish caseworker assignment from actual program enrollment. A first inspection of the data shows that although $25 \%$ of newly unemployed workers in 2001 are assigned to a program only half of them actually enroll. A close examination of unemployment durations, job entries of assigned workers, and the reasons for non-enrollment shows that the difference between assignment and enrollment rates cannot be explained by job entries, program cancelations, or rejected applications alone. This leads us to further analyze the influence of individual characteristics on each stage of the participation process using the 
decomposition framework developed by Heckman and Smith (2004). As the data provide a wide range of personal characteristics and labor market histories, this approach allows us to distinguish between incentives at the official policy or employment office level and the incentives at the individual worker level.

Our results show that observable characteristics have a strong influence at either stage of the participation process. In several ways individual workers either reinforce selection decisions taken at the official level or counteract them. For example, women, married, and older workers, as well as workers with a lot of unemployment in the past have higher probabilities to be assigned to programs. But conditional on assignment, they are also more likely to enroll. On the other hand, workers with the lowest levels of education and low wages are more likely to be assigned but less likely to enroll than workers with at least an apprenticeship degree or higher wages. Similarly, workers who enter unemployment from a job face lower assignment rates but they are more likely to enroll once assigned.

We conclude, that these results demonstrate a high degree of dependence of the participation process on individual incentives. Individual workers have some potential to influence the process at the assignment stage: for example, nonlabor market participants approaching the employment to get access to publicly funded training programs, as well as workers registering early with the AMS before their jobs ends. But their influence is even more important on the enrollment stage where individual workers have the options to negotiate with caseworkers, delay program entry, or simply by not to comply with policy rules. Overall our findings imply that selection is not confined to the caseworker assignment decision. This has important implications for the design of optimal program assignment strategies, where it should be taken into account that observed enrollment rates do not perfectly correspond to caseworker assignment decisions. It may be the case that because of the involvement of individual work- 
ers' interests the caseworker's tasks are indeed more complicated than generally assumed and that they are not so easily outperformed by statistical assignment mechanisms.

Further, the evidence in favor of a strong individual component in the participation decision casts doubts on the credibility of selection on observables assumptions. It might be the case that neither the caseworker nor the researcher are able to observe all information that jointly influences participation and the outcome variables. Research designs that exploit exogenous variation in program participation might therefore provide more reliable results. One potential approach in this direction, would be to examine the considerable degree of heterogeneity in assignment and conditional enrollment rates (in other words program availability) at the local employment office level, which we find in the Austrian data. It indicates that program availability and ALMP strategies vary more or less exogenously across relatively small regions, and offers interesting strategies for additional research. 


\section{References}

Angrist, J. D., Imbens, G. W., Rubin, D. B., 1996. Identification of causal effects using instrumental variables. Journal of the American Statistical Association $91,444-455$.

Arbeitsmarktservice Österreich, 2001. Geschäftsbericht 2000, Wien.

Behncke, S., Froehlich, M., Lechner, M., 2007. Targeting labour market programs: results from a randomized experiment. IZA Discussion Paper (3085).

Currie, J., 2006. The take-up of social benefits. In: Auerbach, A., Card, D., Quigley, J. (Eds.), Poverty, the Distribution of Income, and Public Policy. Russell Sage, New York.

Dehejia, R., 2005. Program evaluation as a decision problem. Journal of Econometrics 125, 141-173.

Dehejia, R. H., Whaba, S., 1999. Causal effects in nonexperimental studies: Reevaluating the evaluation of training programs. Journal of the American Statictical Association 94, 1053-1062.

Heckman, J., 1997. Instrumental variables: a study of implicit behavioral assumptions in one widely used estimator for program evaluations. Journal of Human Resources 32, 441-462.

Heckman, J., Lalonde, R., Smith, J., 1999. The economics and econometrics of active labor market programs. In: Ashenfelter, O., Card, D. (Eds.), Handbook of Labor Economics. Vol. 3a. North Holland, Amsterdam.

Heckman, J. J., Smith, J. A., 1999. The pre-programme earnings dip and the determinants of participation in a social programme. implications for simple programme evaluation strategies. Economic Journal 109, 313-348. 
Heckman, J. J., Smith, J. A., 2004. The determinants of participation in a social program: Evidence from a prototypical job training program. Journal of Labor Economics 22, 243-298.

Hofer, H., Weber, A., 2006. Active labor market policy in Austria: Practice and evaluation results. DIW Quarterly Journal of Economic Research 75, $155-167$.

Lechner, M., Smith, J., 2007. What is the value added by caseworkers? Labour Economics 14, 135-151.

OECD, 2007. Statistical Annex. OECD Employment Outlook 2006, http://www.oecd.org/dataoecd/29/27/38749309.pdf.

Schernhammer, B., Adam, U., 2002. Evaluierung von Jobcoaching 2000. AMS Report (31).

Staghoj, J., Svarer, M., Rosholm, M., 2007. A statistical programme assignment model. IZA Discussion Paper (3165).

Weber, A., 2008. Direct assignment and the evaluation of active labor market policy. Unpublished Manuscript, UC Berkeley. 
Figure 1: Distribution of the time to first program assignment

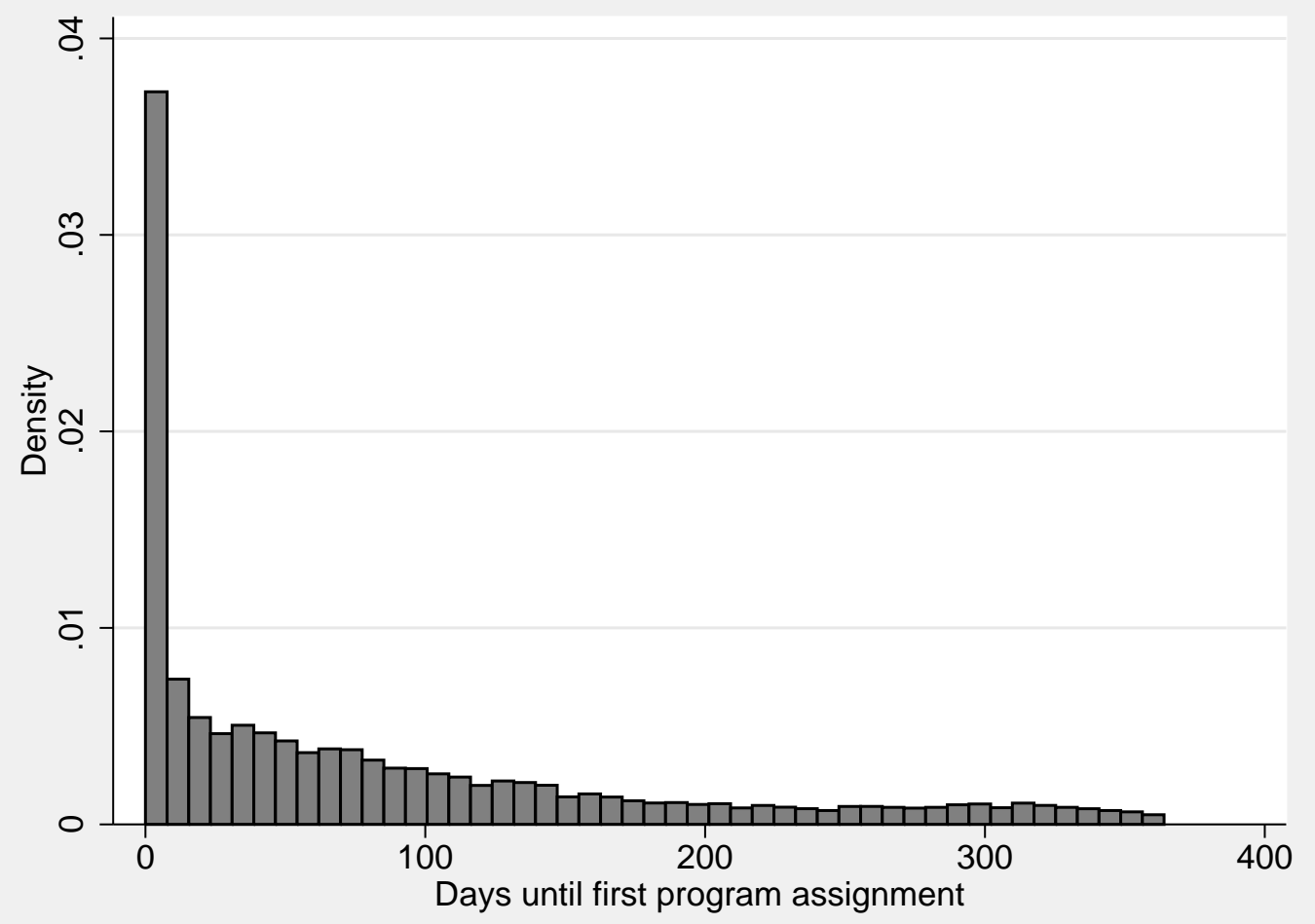

Notes: 2001 inflow into unemployment individuals assigned to at least one program during the first year of unemployment. 
Table 1: Sample Characteristics

\begin{tabular}{|c|c|c|c|c|}
\hline & \multicolumn{2}{|c|}{ All Workers } & \multicolumn{2}{|c|}{$\underline{\text { Female Workers }}$} \\
\hline & Mean & Std.Dev. & Mean & Std.Dev. \\
\hline Assigned to a program & 0.252 & 0.434 & 0.271 & 0.444 \\
\hline Enrolled in a program & 0.122 & 0.327 & 0.135 & 0.342 \\
\hline Female & 0.487 & 0.500 & & \\
\hline Age & 33.4 & 10.4 & 33.2 & 10.2 \\
\hline Married or Living Together & 0.422 & 0.494 & 0.379 & 0.485 \\
\hline \multicolumn{5}{|l|}{ Education } \\
\hline Compulsory or less & 0.392 & 0.488 & 0.407 & 0.491 \\
\hline Apprenticeship & 0.378 & 0.485 & 0.312 & 0.463 \\
\hline Middle School & 0.106 & 0.308 & 0.141 & 0.349 \\
\hline High School & 0.052 & 0.221 & 0.072 & 0.258 \\
\hline Vocational High School & 0.041 & 0.197 & 0.031 & 0.172 \\
\hline University Degree & 0.031 & 0.174 & 0.037 & 0.188 \\
\hline \multicolumn{5}{|l|}{ Occupation } \\
\hline Agriculture & 0.012 & 0.110 & 0.009 & 0.094 \\
\hline Manufacturing & 0.254 & 0.435 & 0.129 & 0.335 \\
\hline Construction & 0.075 & 0.264 & 0.002 & 0.048 \\
\hline Sales & 0.154 & 0.361 & 0.172 & 0.377 \\
\hline Tourism & 0.197 & 0.398 & 0.253 & 0.435 \\
\hline Service & 0.069 & 0.253 & 0.109 & 0.312 \\
\hline Technical & 0.033 & 0.179 & 0.012 & 0.110 \\
\hline Office & 0.136 & 0.342 & 0.209 & 0.407 \\
\hline Health & 0.070 & 0.256 & 0.104 & 0.306 \\
\hline Recalled to previous employer & 0.181 & 0.385 & 0.200 & 0.400 \\
\hline Benefit recipient & 0.843 & 0.364 & 0.826 & 0.379 \\
\hline Registers with AMS before job ends & 0.116 & 0.320 & 0.128 & 0.334 \\
\hline Employed within 30 days before unemployment starts & 0.720 & 0.449 & 0.715 & 0.452 \\
\hline Employed within 90 days before unemployment starts & 0.770 & 0.421 & 0.752 & 0.432 \\
\hline Employed within 180 days before unemployment starts & 0.806 & 0.396 & 0.780 & 0.414 \\
\hline Employed within 360 days before unemployment starts & 0.865 & 0.342 & 0.830 & 0.375 \\
\hline Duration of last Job (months) & 15.9 & 28.0 & 15.9 & 27.3 \\
\hline Monthly wage on last job & $1,386.1$ & 646.5 & $1,172.9$ & 578.6 \\
\hline \multicolumn{5}{|l|}{ Program participations } \\
\hline within 6 months before unemployment & 0.031 & 0.172 & 0.034 & 0.182 \\
\hline within 12 months before unemployment & 0.055 & 0.229 & 0.059 & 0.235 \\
\hline within 18 months before unemployment & 0.046 & 0.209 & 0.046 & 0.209 \\
\hline within 24 months before unemployment & 0.022 & 0.146 & 0.022 & 0.147 \\
\hline within 30 months before unemployment & 0.011 & 0.106 & 0.011 & 0.106 \\
\hline within 36 months before unemployment & 0.005 & 0.067 & 0.005 & 0.067 \\
\hline \multicolumn{5}{|l|}{ Percentage employed } \\
\hline 1st year before unemployment & 0.622 & 0.362 & 0.601 & 0.375 \\
\hline 2nd year before unemployment & 0.598 & 0.386 & 0.553 & 0.401 \\
\hline 3rd year before unemployment & 0.575 & 0.400 & 0.521 & 0.412 \\
\hline 4 th year before unemployment & 0.550 & 0.410 & 0.487 & 0.419 \\
\hline 5 th year before unemployment & 0.521 & 0.419 & 0.455 & 0.425 \\
\hline \multicolumn{5}{|l|}{ Percentage unemployed } \\
\hline 1st year before unemployment & 0.158 & 0.220 & 0.156 & 0.219 \\
\hline 2nd year before unemployment & 0.169 & 0.246 & 0.161 & 0.242 \\
\hline 3rd year before unemployment & 0.162 & 0.250 & 0.154 & 0.248 \\
\hline 4 th year before unemployment & 0.150 & 0.244 & 0.141 & 0.242 \\
\hline 5 th year before unemployment & 0.135 & 0.234 & 0.125 & 0.231 \\
\hline \multicolumn{5}{|l|}{ Number of employment spells } \\
\hline 1st year before unemployment & 1.624 & 1.318 & 1.503 & 1.260 \\
\hline 2nd year before unemployment & 1.484 & 1.305 & 1.326 & 1.216 \\
\hline
\end{tabular}


Table 1 - continued from previous page.

\begin{tabular}{|c|c|c|c|c|}
\hline & \multicolumn{2}{|c|}{ All Workers } & \multicolumn{2}{|c|}{ Female Workers } \\
\hline & Mean & Std.Dev. & Mean & Std.Dev. \\
\hline 3rd year before unemployment & 1.352 & 1.236 & 1.196 & 1.167 \\
\hline 4th year before unemployment & 1.244 & 1.189 & 1.082 & 1.114 \\
\hline 5 th year before unemployment & 1.157 & 1.159 & 0.987 & 1.056 \\
\hline \multicolumn{5}{|l|}{ Number of unemployment spells } \\
\hline 1st year before unemployment & 0.855 & 1.068 & 0.815 & 1.039 \\
\hline 2nd year before unemployment & 0.926 & 1.199 & 0.854 & 1.144 \\
\hline 3rd year before unemployment & 0.837 & 1.172 & 0.765 & 1.124 \\
\hline 4 th year before unemployment & 0.762 & 1.132 & 0.688 & 1.081 \\
\hline 5 th year before unemployment & 0.694 & 1.107 & 0.612 & 1.006 \\
\hline \multicolumn{5}{|l|}{ Average monthly wage } \\
\hline 1st year before unemployment & $1,197.7$ & 710.3 & 970.2 & 629.8 \\
\hline 2nd year before unemployment & $1,130.8$ & 736.1 & 890.7 & 650.3 \\
\hline 3rd year before unemployment & $1,062.3$ & 753.3 & 827.7 & 659.9 \\
\hline 4th year before unemployment & 999.6 & 762.8 & 771.8 & 665.3 \\
\hline 5 th year before unemployment & 946.3 & 777.2 & 722.4 & 675.9 \\
\hline \multicolumn{5}{|l|}{ Percentage on Maternity Leave } \\
\hline 1st year before unemployment & 0.026 & 0.149 & 0.053 & 0.208 \\
\hline 2nd year before unemployment & 0.040 & 0.182 & 0.082 & 0.254 \\
\hline 3rd year before unemployment & 0.040 & 0.178 & 0.081 & 0.247 \\
\hline 4 th year before unemployment & 0.044 & 0.189 & 0.089 & 0.262 \\
\hline 5 th year before unemployment & 0.045 & 0.194 & 0.093 & 0.269 \\
\hline \multicolumn{5}{|l|}{ Month of inflow into unemployment } \\
\hline March & 0.179 & 0.383 & 0.164 & 0.370 \\
\hline April & 0.221 & 0.415 & 0.232 & 0.422 \\
\hline May & 0.185 & 0.388 & 0.182 & 0.386 \\
\hline June & 0.132 & 0.339 & 0.128 & 0.334 \\
\hline July & 0.160 & 0.366 & 0.169 & 0.375 \\
\hline August & 0.123 & 0.328 & 0.125 & 0.331 \\
\hline \multicolumn{5}{|l|}{ Region } \\
\hline Vienna & 0.232 & 0.422 & 0.201 & 0.401 \\
\hline Lower Austria & 0.146 & 0.353 & 0.144 & 0.351 \\
\hline Upper Austria & 0.140 & 0.347 & 0.143 & 0.350 \\
\hline Salzburg & 0.073 & 0.260 & 0.078 & 0.268 \\
\hline Tirol & 0.121 & 0.327 & 0.137 & 0.343 \\
\hline Vorarlberg & 0.042 & 0.200 & 0.045 & 0.208 \\
\hline Burgenland & 0.028 & 0.166 & 0.028 & 0.166 \\
\hline Styria & 0.138 & 0.345 & 0.141 & 0.348 \\
\hline Carinthia & 0.080 & 0.271 & 0.082 & 0.275 \\
\hline Observations & 226,621 & & 110,260 & \\
\hline
\end{tabular}

Note: Sample includes all workers entering unemployment March - August 2001 with a spell of unemployment longer than 1 day and no unemployment during the 30 days prior to this spell, aged 15-65. Average wages are calculated as the average of monthly wages (in Euro, year 2000 prices) in all jobs during the year, and set zero if no wage is reported. 
Table 2: Program Assignment and Enrollment

All Workers

Assigned at least once

$25 \%$

Enrolled at least once

$12 \%$

Number of assignments per individual

Mean Std.dev

Number of enrollments per individual

Individuals

Workers assigned at least once

Number of assignments per individual

Enrolled programs per individual

Individuals

Workers enrolled at least once

Number of assignments per individual

Number of enrollments per individual

$0.43 \quad 0.92$

$0.14 \quad 0.42$

Individuals

226,621

$1.70 \quad 1.09$

$0.57 \quad 0.67$

57,020

$2.03 \quad 1.28$

$1.18 \quad 0.45$

Notes: Sample includes all workers entering unemployment March - August 2001 with a spell of unemployment longer than 1 day and no unemployment during the 30 days prior to this spell, aged 15-65. Assignment occurs if the unemployed receives notice of a program slot, enrollment if the worker participates for more than 5 days in s program. All assignments and enrollments are observed during the first year of the unemployment spell. 
Table 3: Timing of program assignment and enrollment

\begin{tabular}{|c|c|c|c|c|}
\hline & Mean & Median & Std.dev & \\
\hline \multicolumn{5}{|l|}{ All Workers } \\
\hline Time to next job (in days) & 151 & 88 & 136 & \\
\hline Individuals & & & & 226,621 \\
\hline \multicolumn{5}{|l|}{ Workers assigned at least once } \\
\hline Time to next job (in days) & 245 & 287 & 127 & \\
\hline Time until first assignment & 83 & 47 & 97 & \\
\hline Time from first assignment to planned program start & 39 & 21 & 64 & \\
\hline Fraction leaving for a job before planned program start & $13 \%$ & & & \\
\hline Fraction leaving for a job within 2 months of assignment & $28 \%$ & & & \\
\hline Individuals & & & & 57,020 \\
\hline \multicolumn{5}{|l|}{ Workers enrolled at least once } \\
\hline Time to next job (in days) & 277 & 352 & 109 & \\
\hline Time until first assignment & 85 & 55 & 92 & \\
\hline Time until first enrollment & 138 & 111 & 100 & \\
\hline Time from successful assignment to enrollment & 26 & 18 & 25 & \\
\hline Program duration & 74 & 44 & 75 & \\
\hline Individuals & & & & 27,570 \\
\hline
\end{tabular}

Notes: Sample includes all workers entering unemployment March - August 2001 with a spell of unemployment longer than 1 day and no unemployment during the 30 days prior to this spell, aged 15-65. All durations are measured in days. Time to next job is censored at 365 days. For workers who are enrolled at least once assignment and enrollment correspond to the first assignment or enrollment, respectively, in the unemployment spell. If the worker receives multiple assignments before the first enrollment the time between first assignment date and planned first program start does in general not coincide with the time between first assignment date and first enrollment date. In this case the assignment that leads to an enrollment is called the successful assignment. Program duration is the number of days the worker participated in the program.

Table 4: Potential outcomes from first program assignment

Fraction of workers who after the first assignment

Enroll in the program

29.72

Move to a job before the program starts

12.75

Reject participation at the individual level

29.36

Application is rejected

7.26

Course is canceled

20.92

Total

100

Notes: Observations from 57,020 individuals who are assigned to participate in a program at least once during their unemployment spell. Programs with zero enrolled participants are defined as canceled. Workers who do not enroll in the program or move to a job may get re-assigned to another program later in their unemployment spell. 
Table 5: Program types of assignments and enrollments

\begin{tabular}{lrrrrr}
\hline \hline & \multicolumn{2}{c}{ Assignment } & & \multicolumn{2}{c}{ Enrollment } \\
\cline { 2 - 3 } & 5,418 & $9.5 \%$ & 3,300 & $12.0 \%$ \\
Orientation & 12,727 & $22.3 \%$ & 9,740 & $35.3 \%$ \\
Training program & 19,621 & $34.4 \%$ & 12,006 & $43.6 \%$ \\
Job search program & 3,172 & $5.6 \%$ & 1,465 & $5.3 \%$ \\
Public employment program & 16,082 & $28.2 \%$ & 1,059 & $3.8 \%$ \\
Program type unspecified & & & & \\
& 57,020 & 100 & 27,570 & 100 \\
Total & & & & \\
\hline
\end{tabular}

Notes: Program type refers to the first assignment or enrollment, respectively, during an individual's unemployment spell. The program type is unspecified for $84 \%$ of assignments to programs that have no enrolled participants and are thus defined as cancelled. 
Table 6: Determinants of program participation

\begin{tabular}{|c|c|c|c|c|}
\hline & \multicolumn{2}{|c|}{ Assignment } & \multicolumn{2}{|c|}{$\underline{\text { Enrollment }}$} \\
\hline & Coefficient & Std.Err. & Coefficient & Std.Err. \\
\hline Female & 0.196 & $(0.013)^{* *}$ & 0.158 & $(0.022)^{* *}$ \\
\hline Age & 0.018 & $(0.004)^{* *}$ & 0.042 & $(0.006)^{* *}$ \\
\hline Age squared & 0.000 & $(0.000)^{* *}$ & 0.000 & $(0.000)^{* *}$ \\
\hline Married or Living Together & 0.073 & $(0.013)^{* *}$ & 0.166 & $(0.021)^{* *}$ \\
\hline \multicolumn{5}{|l|}{ Education (Compulsory or less) } \\
\hline Apprenticeship & -0.127 & $(0.013)^{* *}$ & 0.079 & $(0.021)^{* *}$ \\
\hline Middle School & -0.051 & $(0.018)^{*}$ & 0.067 & $(0.029)^{*}$ \\
\hline High School & -0.213 & $(0.025)^{* *}$ & 0.071 & $(0.041)$ \\
\hline Vocational High School & -0.334 & $(0.029)^{* *}$ & -0.084 & $(0.047)$ \\
\hline University Degree & -0.367 & $(0.033)^{* *}$ & -0.114 & $(0.055)^{*}$ \\
\hline Recalled to previous employer & -1.209 & $(0.021)^{* *}$ & -0.428 & $(0.041)^{* *}$ \\
\hline \multicolumn{5}{|l|}{ Occupation (Agriculture) } \\
\hline Manufacturing & 0.184 & $(0.050)^{* *}$ & 0.017 & $(0.084)$ \\
\hline Construction & -0.243 & $(0.053)^{* *}$ & -0.094 & $(0.091)$ \\
\hline Sales & 0.263 & $(0.050) * *$ & -0.080 & $(0.085)$ \\
\hline Tourism & -0.403 & $(0.051) * *$ & -0.267 & $(0.087)^{* *}$ \\
\hline Service & -0.127 & $(0.053)^{*}$ & -0.286 & $(0.089)^{* *}$ \\
\hline Technical & 0.554 & $(0.056) * *$ & 0.432 & $(0.093)^{* *}$ \\
\hline Office & 0.525 & $(0.051)^{* *}$ & 0.216 & $(0.085)^{*}$ \\
\hline Health & -0.064 & $(0.053)$ & 0.137 & $(0.090)$ \\
\hline Benefit recipient & 0.502 & $(0.016)^{* *}$ & 0.227 & $(0.028)^{* *}$ \\
\hline $\begin{array}{l}\text { Employed within } 30 \text { days before unemploy- } \\
\text { ment starts }\end{array}$ & -0.216 & $(0.018)^{* *}$ & 0.066 & $(0.029)^{*}$ \\
\hline Registers with AMS before job ends & 0.059 & $(0.017)^{* *}$ & 0.645 & $(0.029)^{* *}$ \\
\hline \multicolumn{5}{|l|}{ Program participation } \\
\hline within 6 months before unemployment & -0.013 & $(0.033)$ & 0.266 & $(0.049)^{* *}$ \\
\hline within 12 months before unemployment & 0.266 & $(0.027)^{* *}$ & 0.249 & $(0.039)^{* *}$ \\
\hline within 18 months before unemployment & 0.162 & $(0.028) * *$ & 0.188 & $(0.041)^{* *}$ \\
\hline within 24 months before unemployment & 0.049 & $(0.038)$ & 0.080 & $(0.057)$ \\
\hline within 30 months before unemployment & 0.082 & $(0.053)$ & 0.056 & $(0.079)$ \\
\hline within 36 months before unemployment & 0.055 & $(0.076)$ & 0.081 & $(0.113)$ \\
\hline \multicolumn{5}{|l|}{ Percentage employed } \\
\hline 1 st year before unemployment & 0.048 & $(0.031)$ & -0.011 & $(0.050)$ \\
\hline 2nd year before unemployment & -0.091 & $(0.028) * *$ & 0.021 & $(0.047)$ \\
\hline 3rd year before unemployment & -0.040 & $(0.029)$ & -0.054 & $(0.047)$ \\
\hline 4 th year before unemployment & 0.013 & $(0.030)$ & -0.009 & $(0.048)$ \\
\hline 5 th year before unemployment & -0.013 & $(0.025)$ & -0.013 & $(0.041)$ \\
\hline \multicolumn{5}{|l|}{ Percentage unemployed } \\
\hline 1st year before unemployment & 0.160 & $(0.037)^{* *}$ & 0.229 & $(0.057)^{* *}$ \\
\hline 2nd year before unemployment & 0.134 & $(0.036)^{* *}$ & -0.051 & $(0.055)$ \\
\hline 3rd year before unemployment & 0.218 & $(0.036)^{* *}$ & -0.059 & $(0.055)$ \\
\hline 4th year before unemployment & 0.211 & $(0.036)^{* *}$ & -0.099 & $(0.055)$ \\
\hline 5 th year before unemployment & 0.167 & $(0.034) * *$ & -0.053 & $(0.052)$ \\
\hline \multicolumn{5}{|l|}{ Number of employment spells } \\
\hline 1st year before unemployment & -0.097 & $(0.007)^{* *}$ & -0.063 & $(0.011)^{* *}$ \\
\hline 2nd year before unemployment & -0.034 & $(0.007)^{* *}$ & -0.013 & $(0.011)$ \\
\hline 3rd year before unemployment & -0.030 & $(0.007)^{* *}$ & -0.041 & $(0.012)^{* *}$ \\
\hline 4 th year before unemployment & -0.012 & $(0.008)$ & -0.031 & $(0.013)^{*}$ \\
\hline 5 th year before unemployment & -0.032 & $(0.008)^{* *}$ & -0.008 & $(0.012)$ \\
\hline \multicolumn{5}{|l|}{ Number of unemployment spells } \\
\hline 1st year before unemployment & -0.100 & $(0.009)^{* *}$ & 0.028 & $(0.014)^{*}$ \\
\hline 2nd year before unemployment & -0.021 & $(0.008)^{*}$ & 0.004 & $(0.013)$ \\
\hline 3rd year before unemployment & -0.060 & $(0.009)^{* *}$ & 0.001 & $(0.014)$ \\
\hline 4th year before unemployment & -0.025 & $(0.009)^{*}$ & 0.030 & $(0.014)^{*}$ \\
\hline
\end{tabular}


Table 6 - continued from previous page.

\begin{tabular}{|c|c|c|c|c|}
\hline & \multicolumn{2}{|c|}{ Assignment } & \multicolumn{2}{|c|}{$\underline{\text { Enrollment }}$} \\
\hline & Coefficient & Std.Err. & Coefficient & Std.Err. \\
\hline 5 th year before unemployment & -0.005 & $(0.009)$ & -0.003 & $(0.014)$ \\
\hline Average monthly wage & & & & \\
\hline 1st year before unemployment & -0.036 & $(0.013)^{*}$ & 0.071 & $(0.021)^{* *}$ \\
\hline 2nd year before unemployment & -0.045 & $(0.014)^{* *}$ & -0.011 & $(0.023)$ \\
\hline 3rd year before unemployment & 0.013 & $(0.015)$ & 0.004 & $(0.024)$ \\
\hline 4 th year before unemployment & -0.006 & $(0.015)$ & 0.048 & $(0.024)^{*}$ \\
\hline 5 th year before unemployment & -0.022 & $(0.014)$ & -0.040 & $(0.022)$ \\
\hline \multicolumn{5}{|l|}{ Month of inflow (August) } \\
\hline March & 0.104 & $(0.019)^{* *}$ & -0.042 & $(0.031)$ \\
\hline April & -0.021 & $(0.019)$ & -0.119 & $(0.031)^{* *}$ \\
\hline May & -0.041 & $(0.019)^{*}$ & -0.109 & $(0.031)^{* *}$ \\
\hline June & -0.036 & $(0.020)$ & -0.061 & $(0.032)$ \\
\hline July & -0.030 & $(0.019)$ & 0.010 & $(0.031)$ \\
\hline \multicolumn{5}{|l|}{ Region (Carinthia) } \\
\hline Vienna & 1.093 & $(0.023)^{* *}$ & -0.093 & $(0.041)^{*}$ \\
\hline Lower Austria & 0.609 & $(0.024)^{* *}$ & -0.614 & $(0.043)^{* *}$ \\
\hline Upper Austria & 0.083 & $(0.025)^{* *}$ & 0.075 & $(0.046)$ \\
\hline Salzburg & -0.408 & $(0.034)^{* *}$ & -0.184 & $(0.062)^{* *}$ \\
\hline Tirol & -0.560 & $(0.031)^{* *}$ & -0.073 & $(0.058)$ \\
\hline Vorarlberg & 0.292 & $(0.034)^{* *}$ & -0.151 & $(0.059) *$ \\
\hline Burgenland & 0.429 & $(0.036)^{* *}$ & 0.143 & $(0.062) *$ \\
\hline Styria & 0.412 & $(0.025)^{* *}$ & -0.089 & $(0.044)^{*}$ \\
\hline Constant & -1.687 & $(0.085)^{* *}$ & -1.225 & $(0.142)^{* *}$ \\
\hline Observations & 226,621 & & 57,020 & \\
\hline
\end{tabular}

Note: Estimation results from logit models of assignment and enrollment conditional on assignment on individual characteristics. The sample includes all workers entering unemployment March - August 2001 with a spell of unemployment longer than 1 day and no unemployment during the 30 days prior to this spell, aged 15-65. Average wages are calculated as the average of monthly wages (in Euro, year 2000 prices) in all jobs during the year, and set zero if no wage is reported. 
Table 7: Contributions of the Assignment and Enrollment Stage towards Program Participation

\begin{tabular}{|c|c|c|c|c|c|c|c|}
\hline & \multicolumn{2}{|l|}{$\underline{\text { Overall }}$} & \multicolumn{2}{|l|}{ Assignment } & \multicolumn{3}{|c|}{$\underline{\text { Enrollment }}$} \\
\hline & $\begin{array}{l}\text { Marginal } \\
\text { Effect }\end{array}$ & $\begin{array}{l}\text { Marginal } \\
\text { Effect }\end{array}$ & Std.Err. & $\begin{array}{l}\text { Percent } \\
\text { of Overall }\end{array}$ & $\begin{array}{l}\text { Marginal } \\
\text { Effect }\end{array}$ & Std.Err. & $\begin{array}{l}\text { Percent } \\
\text { of Overall }\end{array}$ \\
\hline Female & 0.026 & 0.030 & $(0.002)^{* *}$ & $20 \%$ & 0.039 & $(0.005)^{* *}$ & $80 \%$ \\
\hline Age & 0.006 & 0.003 & $(0.001)^{* *}$ & $8 \%$ & 0.010 & $(0.002)^{* *}$ & $92 \%$ \\
\hline Age squared & 0.000 & 0.000 & $(0.000)^{* *}$ & $11 \%$ & 0.000 & $(0.000)^{* *}$ & $89 \%$ \\
\hline $\begin{array}{l}\text { Married or Living Together } \\
\text { Education (Compulsory or less) }\end{array}$ & 0.023 & 0.011 & $(0.002)^{* *}$ & $8 \%$ & 0.041 & $(0.005)^{* *}$ & $92 \%$ \\
\hline Apprenticeship & 0.007 & -0.017 & $(0.002)^{* *}$ & $-42 \%$ & 0.020 & $(0.005)^{* *}$ & $142 \%$ \\
\hline Middle School & 0.007 & -0.007 & $(0.003)^{*}$ & $-17 \%$ & 0.017 & $(0.007)^{*}$ & $117 \%$ \\
\hline High School & 0.004 & -0.028 & $(0.003)^{* *}$ & $-115 \%$ & 0.018 & $(0.010)$ & $215 \%$ \\
\hline Vocational High School & -0.018 & -0.043 & $(0.004)^{* *}$ & $41 \%$ & -0.021 & $(0.012)$ & $59 \%$ \\
\hline University Degree & -0.023 & -0.047 & $(0.004)^{* *}$ & $35 \%$ & -0.028 & $(0.014)^{*}$ & $65 \%$ \\
\hline $\begin{array}{l}\text { Recalled to previous employer } \\
\text { Occupation (Agriculture) }\end{array}$ & -0.075 & -0.115 & $(0.005)^{* *}$ & $26 \%$ & -0.106 & $(0.010)^{* *}$ & $74 \%$ \\
\hline Manufacturing & 0.007 & 0.028 & $(0.007)^{* *}$ & $69 \%$ & 0.004 & $(0.021)$ & $31 \%$ \\
\hline Construction & -0.018 & -0.032 & $(0.007)^{* *}$ & $31 \%$ & -0.023 & $(0.023)$ & $69 \%$ \\
\hline Sales & -0.003 & 0.041 & $(0.007)^{* *}$ & $-212 \%$ & -0.020 & $(0.021)$ & $312 \%$ \\
\hline Tourism & -0.043 & -0.050 & $(0.007)^{* *}$ & $20 \%$ & -0.067 & $(0.022) * *$ & $80 \%$ \\
\hline Service & -0.040 & -0.017 & $(0.007)^{*}$ & $8 \%$ & -0.071 & $(0.022)^{* *}$ & $92 \%$ \\
\hline Technical & 0.071 & 0.094 & $(0.009)^{* *}$ & $23 \%$ & 0.105 & $(0.023)^{* *}$ & $77 \%$ \\
\hline Office & 0.043 & 0.088 & $(0.008)^{* *}$ & $36 \%$ & 0.053 & $(0.021)^{*}$ & $64 \%$ \\
\hline Health & 0.016 & -0.009 & $(0.008)$ & $-10 \%$ & 0.034 & $(0.022)$ & $110 \%$ \\
\hline Benefit recipient & 0.040 & 0.061 & $(0.003)^{* *}$ & $26 \%$ & 0.057 & $(0.007)^{* *}$ & $74 \%$ \\
\hline Employed within 30 days & & & & & & & \\
\hline $\begin{array}{l}\text { before unemployment starts } \\
\text { Registers with AMS }\end{array}$ & 0.003 & -0.033 & $(0.003)^{* *}$ & $-202 \%$ & 0.017 & $(0.007)^{*}$ & $302 \%$ \\
\hline before job ends & 0.082 & 0.009 & $(0.003)^{* *}$ & $2 \%$ & 0.154 & $(0.007)^{* *}$ & $98 \%$ \\
\hline Program participation & & & & & & & \\
\hline within 6 months before & 0.034 & -0.002 & $(0.005)^{*}$ & $-1 \%$ & 0.066 & $(0.012)^{* *}$ & $101 \%$ \\
\hline within 12 months before & 0.039 & 0.042 & $(0.005)^{* *}$ & $18 \%$ & 0.061 & $(0.010)^{* *}$ & $82 \%$ \\
\hline within 18 months before & 0.029 & 0.024 & $(0.004)^{* *}$ & $15 \%$ & 0.047 & $(0.010)^{* *}$ & $85 \%$ \\
\hline within 24 months before & 0.012 & 0.007 & $(0.006)$ & $11 \%$ & 0.020 & $(0.014)$ & $89 \%$ \\
\hline within 30 months before & 0.009 & 0.012 & $(0.008)$ & $23 \%$ & 0.014 & $(0.020)$ & $77 \%$ \\
\hline within 36 months before & 0.012 & 0.008 & $(0.011)$ & $12 \%$ & 0.020 & $(0.028)$ & $88 \%$ \\
\hline Percentage employed & & & & & & & \\
\hline 1st year before unemployment & 0.000 & 0.007 & $(0.004)$ & $-498 \%$ & -0.003 & $(0.013)$ & $598 \%$ \\
\hline 2nd year before unemployment & 0.001 & -0.013 & $(0.004)^{* *}$ & $-444 \%$ & 0.005 & $(0.012)$ & $544 \%$ \\
\hline 3rd year before unemployment & -0.008 & -0.006 & $(0.004)$ & $13 \%$ & -0.013 & $(0.012)$ & $87 \%$ \\
\hline 4 th year before unemployment & -0.001 & 0.002 & $(0.004)$ & $-39 \%$ & -0.002 & $(0.012)$ & $139 \%$ \\
\hline $\begin{array}{l}5 \text { th year before unemployment } \\
\text { Percentage unemployed }\end{array}$ & -0.002 & -0.002 & $(0.004)$ & $17 \%$ & -0.003 & $(0.010)$ & $83 \%$ \\
\hline 1st year before unemployment & 0.034 & 0.023 & $(0.005)^{* *}$ & $12 \%$ & 0.057 & $(0.014)^{* *}$ & $88 \%$ \\
\hline 2nd year before unemployment & -0.003 & 0.019 & $(0.005)^{* *}$ & $-102 \%$ & -0.013 & $(0.014)$ & $202 \%$ \\
\hline 3rd year before unemployment & -0.002 & 0.031 & $(0.005)^{* *}$ & $-237 \%$ & -0.015 & $(0.014)$ & $337 \%$ \\
\hline 4th year before unemployment & -0.008 & 0.030 & $(0.005) * *$ & $-69 \%$ & -0.025 & $(0.014)$ & $169 \%$ \\
\hline 5 th year before unemployment & -0.003 & 0.024 & $(0.005)^{* *}$ & $-148 \%$ & -0.013 & $(0.013)$ & $248 \%$ \\
\hline Number of employment spells & & & & & & & \\
\hline 1st year before unemployment & -0.011 & -0.014 & $(0.001)^{* *}$ & $23 \%$ & -0.016 & $(0.003)^{* *}$ & $77 \%$ \\
\hline 2nd year before unemployment & -0.003 & -0.005 & $(0.001)^{* *}$ & $33 \%$ & -0.003 & $(0.003)$ & $67 \%$ \\
\hline 3rd year before unemployment & -0.006 & -0.004 & $(0.001)^{* *}$ & $12 \%$ & -0.010 & $(0.003)^{* *}$ & $88 \%$ \\
\hline 4th year before unemployment & -0.004 & -0.002 & $(0.001)$ & $7 \%$ & -0.008 & $(0.003)^{*}$ & $93 \%$ \\
\hline $\begin{array}{l}5 \text { th year before unemployment } \\
\text { Number of unemployment spells }\end{array}$ & -0.002 & -0.005 & $(0.001)^{* *}$ & $43 \%$ & -0.002 & $(0.003)$ & $57 \%$ \\
\hline
\end{tabular}


Table 7 - continued from previous page.

\begin{tabular}{|c|c|c|c|c|c|c|c|}
\hline & \multirow{2}{*}{$\begin{array}{c}\text { Overall } \\
\text { Marginal } \\
\text { Effect }\end{array}$} & \multicolumn{3}{|c|}{ Assignment } & \multicolumn{3}{|c|}{ Enrollment } \\
\hline & & $\begin{array}{l}\text { Marginal } \\
\text { Effect }\end{array}$ & Std.Err. & $\begin{array}{l}\text { Percent } \\
\text { of Overall }\end{array}$ & $\begin{array}{l}\text { Marginal } \\
\text { Effect }\end{array}$ & Std.Err. & $\begin{array}{l}\text { Percent } \\
\text { of Overall }\end{array}$ \\
\hline 1st year before unemployment & 0.001 & -0.014 & $(0.001)^{* *}$ & $-229 \%$ & 0.007 & $(0.004)^{*}$ & $329 \%$ \\
\hline 2nd year before unemployment & 0.000 & -0.003 & $(0.001)^{*}$ & $1011 \%$ & 0.001 & $(0.003)$ & $-911 \%$ \\
\hline 3rd year before unemployment & -0.001 & -0.009 & $(0.001)^{* *}$ & $111 \%$ & 0.000 & $(0.003)$ & $-11 \%$ \\
\hline 4th year before unemployment & 0.003 & -0.004 & $(0.001)^{*}$ & $-19 \%$ & 0.008 & $(0.003) *$ & $119 \%$ \\
\hline $\begin{array}{l}\text { 5th year before unemployment } \\
\text { Average monthly wage }\end{array}$ & -0.001 & -0.001 & $(0.001)$ & $22 \%$ & -0.001 & $(0.003)$ & $78 \%$ \\
\hline 1st year before unemployment & 0.008 & -0.005 & $(0.002)^{*}$ & $-11 \%$ & 0.018 & $(0.005)^{* *}$ & $111 \%$ \\
\hline 2nd year before unemployment & -0.003 & -0.007 & $(0.002)^{* *}$ & $44 \%$ & -0.003 & $(0.006)$ & $56 \%$ \\
\hline 3rd year before unemployment & 0.001 & 0.002 & $(0.002)$ & $35 \%$ & 0.001 & $(0.006)$ & $65 \%$ \\
\hline 4th year before unemployment & 0.006 & -0.001 & $(0.002)$ & $-2 \%$ & 0.012 & $(0.006)^{*}$ & $102 \%$ \\
\hline $\begin{array}{l}5 \text { th year before unemployment } \\
\text { Month of inflow (August) }\end{array}$ & -0.006 & -0.003 & $(0.002)$ & $10 \%$ & -0.010 & $(0.006)$ & $90 \%$ \\
\hline March & -0.003 & 0.016 & $(0.003)^{* *}$ & $-97 \%$ & -0.010 & $(0.008)$ & $197 \%$ \\
\hline April & -0.016 & -0.003 & $(0.003)$ & $3 \%$ & -0.030 & $(0.008)^{* *}$ & $97 \%$ \\
\hline May & -0.015 & -0.006 & $(0.003)^{*}$ & $7 \%$ & -0.027 & $(0.008)^{* *}$ & $93 \%$ \\
\hline June & -0.009 & -0.005 & $(0.003)$ & $10 \%$ & -0.015 & $(0.008)$ & $90 \%$ \\
\hline July & 0.001 & -0.004 & $(0.003)$ & $-129 \%$ & 0.002 & $(0.008)$ & $229 \%$ \\
\hline Region (Carinthia) & & & & & & & \\
\hline Vienna & 0.025 & 0.212 & $(0.006)^{* *}$ & $150 \%$ & -0.023 & $(0.010)^{*}$ & $-50 \%$ \\
\hline Lower Austria & -0.060 & 0.105 & $(0.005)^{* *}$ & $-30 \%$ & -0.150 & $(0.011)^{* *}$ & $130 \%$ \\
\hline Upper Austria & 0.012 & 0.012 & $(0.004)^{* *}$ & $18 \%$ & 0.019 & $(0.011)$ & $82 \%$ \\
\hline Salzburg & -0.033 & -0.051 & $(0.005)^{* *}$ & $27 \%$ & -0.046 & $(0.016)^{* *}$ & $73 \%$ \\
\hline Tirol & -0.021 & -0.066 & $(0.005)^{* *}$ & $55 \%$ & -0.018 & $(0.015)$ & $45 \%$ \\
\hline Vorarlberg & -0.012 & 0.046 & $(0.006)^{* *}$ & $-68 \%$ & -0.038 & $(0.015)^{*}$ & $168 \%$ \\
\hline Burgenland & 0.031 & 0.070 & $(0.007)^{* *}$ & $40 \%$ & 0.035 & $(0.015)^{*}$ & $60 \%$ \\
\hline Styria & 0.000 & 0.067 & $(0.004)^{* *}$ & $24958 \%$ & -0.022 & $(0.011)^{*}$ & $-24858 \%$ \\
\hline Observations & 226,621 & 226,621 & & & 57,020 & & \\
\hline
\end{tabular}

Note: Marginal effects from logit models of assignment and enrollment conditional on individual characteristics in columns 3 and 6. Marginal effects evaluated at the median worker characteristics. See text for the calculation of the overall effect in column 1. Columns 5 and 8 give the percentage share of the effects at the assignment and enrollment stages in the overall effect. The sample includes all workers entering unemployment March - August 2001 with a spell of unemployment longer than 1 day and no unemployment during the 30 days prior to this spell, aged 15-65. Average wages are calculated as the average of monthly wages (in Euro, year 2000 prices) in all jobs during the year, and set zero if no wage is reported. 
Table 8: Determinants of female program participation

\begin{tabular}{|c|c|c|c|c|}
\hline & \multicolumn{2}{|c|}{ Assignment } & \multicolumn{2}{|c|}{$\underline{\text { Enrollment }}$} \\
\hline & Coefficient & Std.Err. & Coefficient & Std.Err. \\
\hline Age & 0.021 & $(0.006)^{* *}$ & 0.070 & $(0.010)^{* *}$ \\
\hline Age squared & 0.000 & $(0.000)^{* *}$ & -0.001 & $(0.000)^{* *}$ \\
\hline Married or Living Together & 0.071 & $(0.019)^{* *}$ & 0.124 & $(0.030)^{* *}$ \\
\hline \multicolumn{5}{|l|}{ Education (Compulsory or less) } \\
\hline Apprenticeship & -0.113 & $(0.019)^{* *}$ & 0.070 & $(0.031)^{*}$ \\
\hline Middle School & -0.071 & $(0.023)^{* *}$ & 0.043 & $(0.037)$ \\
\hline High School & -0.256 & $(0.032)^{* *}$ & -0.001 & $(0.051)$ \\
\hline Vocational High School & -0.365 & $(0.044)^{* *}$ & -0.077 & $(0.071)$ \\
\hline University Degree & -0.318 & $(0.044)^{* *}$ & -0.047 & $(0.072)$ \\
\hline \multicolumn{5}{|l|}{ Occupation (Agriculture) } \\
\hline Manufacturing & 0.273 & $(0.080)^{* *}$ & -0.098 & $(0.135)$ \\
\hline Construction & 0.226 & $(0.163)$ & -0.126 & $(0.271)$ \\
\hline Sales & 0.362 & $(0.079)^{* *}$ & -0.154 & $(0.134)$ \\
\hline Tourism & -0.271 & $(0.080)^{* *}$ & -0.363 & $(0.136)^{*}$ \\
\hline Service & -0.084 & $(0.081)$ & -0.431 & $(0.136)^{* *}$ \\
\hline Technical & 0.686 & $(0.098) * *$ & 0.525 & $(0.160)^{* *}$ \\
\hline Office & 0.619 & $(0.079) * *$ & 0.108 & $(0.133)$ \\
\hline Health & 0.012 & $(0.081)$ & -0.017 & $(0.137)$ \\
\hline Recalled to previous employer & -1.337 & $(0.031)^{* *}$ & -0.494 & $(0.059)^{* *}$ \\
\hline Benefit recipient & 0.363 & $(0.024)^{* *}$ & 0.180 & $(0.041)^{* *}$ \\
\hline Registers with AMS before job ends & 0.012 & $(0.023)$ & 0.624 & $(0.039)^{* *}$ \\
\hline $\begin{array}{l}\text { Employed within } 30 \text { days before unemploy- } \\
\text { ment starts }\end{array}$ & -0.204 & $(0.027)^{* *}$ & 0.082 & $(0.043)$ \\
\hline \multicolumn{5}{|l|}{ Program participations } \\
\hline within 6 months before unemployment & -0.036 & $(0.045)$ & 0.207 & $(0.068)^{* *}$ \\
\hline within 12 months before unemployment & 0.285 & $(0.038) * *$ & 0.267 & $(0.057)^{* *}$ \\
\hline within 18 months before unemployment & 0.151 & $(0.040)^{* *}$ & 0.142 & $(0.059)^{*}$ \\
\hline within 24 months before unemployment & 0.071 & $(0.054)$ & -0.029 & $(0.080)$ \\
\hline within 30 months before unemployment & 0.142 & $(0.075)$ & 0.052 & $(0.110)$ \\
\hline within 36 months before unemployment & -0.120 & $(0.110)$ & 0.094 & $(0.168)$ \\
\hline \multicolumn{5}{|l|}{ Percentage employed } \\
\hline 1st year before unemployment & 0.079 & $(0.048)$ & -0.108 & $(0.077)$ \\
\hline 2nd year before unemployment & -0.007 & $(0.044)$ & -0.046 & $(0.073)$ \\
\hline 3rd year before unemployment & -0.074 & $(0.046)$ & 0.017 & $(0.075)$ \\
\hline 4th year before unemployment & 0.073 & $(0.047)$ & -0.088 & $(0.077)$ \\
\hline 5 th year before unemployment & -0.051 & $(0.039)$ & 0.099 & $(0.064)$ \\
\hline \multicolumn{5}{|l|}{ Percentage unemployed } \\
\hline 1st year before unemployment & 0.129 & $(0.055)^{*}$ & 0.103 & $(0.086)$ \\
\hline 2nd year before unemployment & 0.203 & $(0.054) * *$ & -0.146 & $(0.085)$ \\
\hline 3rd year before unemployment & 0.174 & $(0.055) * *$ & -0.093 & $(0.085)$ \\
\hline 4th year before unemployment & 0.258 & $(0.056)^{* *}$ & -0.230 & $(0.086)^{*}$ \\
\hline 5 th year before unemployment & 0.147 & $(0.052)^{*}$ & -0.044 & $(0.080)$ \\
\hline \multicolumn{5}{|l|}{ Percentage on maternity leave } \\
\hline 1st year before unemployment & 0.073 & $(0.061)$ & -0.111 & $(0.094)$ \\
\hline 2nd year before unemployment & 0.269 & $(0.067)^{* *}$ & -0.151 & $(0.105)$ \\
\hline 3rd year before unemployment & -0.009 & $(0.061)$ & -0.001 & $(0.096)$ \\
\hline 4 th year before unemployment & 0.129 & $(0.061)^{*}$ & -0.112 & $(0.096)$ \\
\hline 5 th year before unemployment & 0.025 & $(0.048)$ & -0.088 & $(0.076)$ \\
\hline \multicolumn{5}{|l|}{ Number of employment spells } \\
\hline 1st year before unemployment & -0.093 & $(0.011)^{* *}$ & -0.077 & $(0.017)^{* *}$ \\
\hline 2nd year before unemployment & -0.022 & $(0.011)^{*}$ & -0.014 & $(0.017)$ \\
\hline 3rd year before unemployment & -0.042 & $(0.012)^{* *}$ & -0.080 & $(0.020)^{* *}$ \\
\hline 4 th year before unemployment & 0.013 & $(0.012)$ & -0.011 & $(0.019)$ \\
\hline 5 th year before unemployment & -0.047 & $(0.013)^{* *}$ & -0.039 & $(0.020)$ \\
\hline Number of unemployment spells & & & & \\
\hline
\end{tabular}


Table $8-$ continued from previous page.

\begin{tabular}{|c|c|c|c|c|}
\hline & \multicolumn{2}{|c|}{ Assignment } & \multicolumn{2}{|c|}{ Enrollment } \\
\hline & Coefficient & Std.Err. & Coefficient & Std.Err. \\
\hline 1st year before unemployment & -0.152 & $(0.014)^{* *}$ & 0.037 & $(0.021)$ \\
\hline 2nd year before unemployment & -0.052 & $(0.012)^{* *}$ & 0.012 & $(0.020)$ \\
\hline 3rd year before unemployment & -0.057 & $(0.013)^{* *}$ & 0.060 & $(0.021)^{*}$ \\
\hline 4 th year before unemployment & -0.039 & $(0.013) *$ & 0.031 & $(0.021)$ \\
\hline 5 th year before unemployment & -0.025 & $(0.014)$ & 0.020 & $(0.023)$ \\
\hline \multicolumn{5}{|l|}{ Average monthly wage } \\
\hline 1st year before unemployment & -0.037 & $(0.020)$ & 0.099 & $(0.033)^{* *}$ \\
\hline 2nd year before unemployment & -0.031 & $(0.022)$ & -0.025 & $(0.036)$ \\
\hline 3rd year before unemployment & 0.021 & $(0.023)$ & 0.048 & $(0.037)$ \\
\hline 4th year before unemployment & -0.039 & $(0.024)$ & -0.004 & $(0.037)$ \\
\hline 5 th year before unemployment & -0.023 & $(0.022)$ & -0.072 & $(0.035) *$ \\
\hline \multicolumn{5}{|l|}{ Month of inflow (August) } \\
\hline March & 0.187 & $(0.027)^{* *}$ & -0.028 & $(0.043)$ \\
\hline April & 0.035 & $(0.026)$ & -0.136 & $(0.042)^{* *}$ \\
\hline May & 0.011 & $(0.027)$ & -0.131 & $(0.043)^{* *}$ \\
\hline June & 0.006 & $(0.028)$ & -0.086 & $(0.044)$ \\
\hline July & -0.001 & $(0.026)$ & -0.047 & $(0.042)$ \\
\hline \multicolumn{5}{|l|}{ Region (Carinthia) } \\
\hline Vienna & 0.833 & $(0.032)^{* *}$ & -0.185 & $(0.053)^{* *}$ \\
\hline Lower Austria & 0.377 & $(0.033)^{* *}$ & -0.668 & $(0.057)^{* *}$ \\
\hline Upper Austria & -0.079 & $(0.034) *$ & 0.000 & $(0.059)$ \\
\hline Salzburg & -0.469 & $(0.044)^{* *}$ & -0.260 & $(0.080)^{* *}$ \\
\hline Tirol & -0.617 & $(0.041)^{* *}$ & -0.228 & $(0.075)^{* *}$ \\
\hline Vorarlberg & 0.360 & $(0.044)^{* *}$ & -0.256 & $(0.074)^{* *}$ \\
\hline Burgenland & 0.252 & $(0.049)^{* *}$ & 0.031 & $(0.082)$ \\
\hline Styria & 0.364 & $(0.033)^{* *}$ & -0.155 & $(0.057)^{*}$ \\
\hline Constant & $\begin{array}{l}0.004 \\
-1.482\end{array}$ & $(0.128)^{* *}$ & -1.050 & $(0.214)^{* *}$ \\
\hline Observations & 110,260 & & 29,834 & \\
\hline
\end{tabular}

Note: Estimation results from logit models of assignment and enrollment conditional on assignment on individual characteristics. The sample includes all female workers entering unemployment March - August 2001 with a spell of unemployment longer than 1 day and no unemployment during the 30 days prior to this spell, aged 15-65. Average wages are calculated as the average of monthly wages (in Euro, year 2000 prices) in all jobs during the year, and set zero if no wage is reported. 
Table 9: Determinants of male program participation

\begin{tabular}{|c|c|c|c|c|}
\hline & \multicolumn{2}{|c|}{ Assignment } & \multicolumn{2}{|c|}{ Enrollment } \\
\hline & Coefficient & Std.Err. & Coefficient & Std.Err. \\
\hline Age & 0.001 & $(0.005)$ & 0.042 & $(0.009)^{* *}$ \\
\hline Age squared & 0.000 & $(0.000)$ & 0.000 & $(0.000)$ \\
\hline Married or Living Together & 0.142 & $(0.018) * *$ & 0.166 & $(0.030) * *$ \\
\hline \multicolumn{5}{|l|}{ Education (Compulsory or less) } \\
\hline Apprenticeship & -0.160 & $(0.018)^{* *}$ & 0.079 & $(0.030)^{*}$ \\
\hline Middle School & 0.002 & $(0.029)$ & 0.067 & $(0.048) *$ \\
\hline High School & -0.098 & $(0.043)^{*}$ & 0.071 & $(0.069)^{*}$ \\
\hline Vocational High School & -0.298 & $(0.039)^{* *}$ & -0.084 & $(0.064)$ \\
\hline University Degree & -0.419 & $(0.052)^{* *}$ & -0.114 & $(0.086)^{* *}$ \\
\hline \multicolumn{5}{|l|}{ Occupation (Agriculture) } \\
\hline Manufacturing & 0.138 & $(0.064)^{*}$ & 0.017 & $(0.109)$ \\
\hline Construction & -0.324 & $(0.066)^{* *}$ & -0.094 & $(0.113)$ \\
\hline Sales & 0.200 & $(0.066)^{* *}$ & -0.080 & $(0.112)$ \\
\hline Tourism & -0.492 & $(0.068)^{* *}$ & -0.267 & $(0.118)$ \\
\hline Service & 0.052 & $(0.075)$ & -0.286 & $(0.127)$ \\
\hline Technical & 0.521 & $(0.071)^{* *}$ & 0.432 & $(0.118)^{* *}$ \\
\hline Office & 0.486 & $(0.068)^{* *}$ & 0.216 & $(0.115)^{*}$ \\
\hline Health & -0.039 & $(0.075)$ & 0.137 & $(0.129)^{*}$ \\
\hline Recalled to previous employer & -1.072 & $(0.030)^{* *}$ & -0.428 & $(0.058)^{* *}$ \\
\hline Benefit recipient & 0.574 & $(0.025)^{* *}$ & 0.227 & $(0.044)^{* *}$ \\
\hline Registers with AMS before job ends & 0.110 & $(0.025)^{* *}$ & 0.645 & $(0.043)^{* *}$ \\
\hline $\begin{array}{l}\text { Employed within } 30 \text { days before unemploy- } \\
\text { ment starts }\end{array}$ & -0.253 & $(0.024)^{* *}$ & 0.066 & $(0.039)$ \\
\hline \multicolumn{5}{|l|}{ Program participations } \\
\hline within 6 months before unemployment & 0.059 & $(0.048)$ & 0.266 & $(0.071)^{* *}$ \\
\hline within 12 months before unemployment & 0.270 & $(0.038)^{* *}$ & 0.249 & $(0.055)^{* *}$ \\
\hline within 18 months before unemployment & 0.173 & $(0.038)^{* *}$ & 0.188 & $(0.057)^{* *}$ \\
\hline within 24 months before unemployment & 0.073 & $(0.055)$ & 0.080 & $(0.081)^{*}$ \\
\hline within 30 months before unemployment & 0.035 & $(0.076)$ & 0.056 & $(0.113)$ \\
\hline within 36 months before unemployment & 0.217 & $(0.106)^{*}$ & 0.081 & $(0.154)$ \\
\hline \multicolumn{5}{|l|}{ Percentage employed } \\
\hline 1st year before unemployment & 0.149 & $(0.044)^{* *}$ & -0.011 & $(0.073)$ \\
\hline 2nd year before unemployment & 0.041 & $(0.042)$ & 0.021 & $(0.070)$ \\
\hline 3rd year before unemployment & -0.033 & $(0.043)$ & -0.054 & $(0.073)$ \\
\hline 4 th year before unemployment & 0.002 & $(0.044)$ & -0.009 & $(0.073)$ \\
\hline 5 th year before unemployment & 0.003 & $(0.037)$ & -0.013 & $(0.062)$ \\
\hline \multicolumn{5}{|l|}{ Percentage unemployed } \\
\hline 1st year before unemployment & 0.292 & $(0.053)^{* *}$ & 0.229 & $(0.082)^{* *}$ \\
\hline 2nd year before unemployment & 0.257 & $(0.052)^{* *}$ & -0.051 & $(0.082)$ \\
\hline 3rd year before unemployment & 0.227 & $(0.054)^{* *}$ & -0.059 & $(0.085)$ \\
\hline 4th year before unemployment & 0.210 & $(0.055)^{* *}$ & -0.099 & $(0.086)$ \\
\hline 5 th year before unemployment & 0.181 & $(0.051)^{* *}$ & -0.053 & $(0.078)$ \\
\hline \multicolumn{5}{|l|}{ Number of employment spells } \\
\hline 1st year before unemployment & -0.096 & $(0.009)^{* *}$ & -0.063 & $(0.015)^{* *}$ \\
\hline 2nd year before unemployment & -0.044 & $(0.009)^{* *}$ & -0.013 & $(0.014)$ \\
\hline 3rd year before unemployment & -0.022 & $(0.009) *$ & -0.041 & $(0.015)$ \\
\hline 4 th year before unemployment & -0.029 & $(0.010)^{*}$ & -0.031 & $(0.017)^{*}$ \\
\hline 5 th year before unemployment & -0.025 & $(0.010)^{*}$ & -0.008 & $(0.016)$ \\
\hline \multicolumn{5}{|l|}{ Number of unemployment spells } \\
\hline 1st year before unemployment & -0.058 & $(0.012)^{* *}$ & 0.028 & $(0.019)$ \\
\hline 2nd year before unemployment & 0.011 & $(0.011)$ & 0.004 & $(0.017)$ \\
\hline 3rd year before unemployment & -0.062 & $(0.012)^{* *}$ & 0.001 & $(0.018)^{*}$ \\
\hline 4th year before unemployment & -0.017 & $(0.012)$ & 0.030 & $(0.019)$ \\
\hline 5 th year before unemployment & 0.005 & $(0.012)$ & -0.003 & $(0.018)$ \\
\hline Average monthly wage & & & & \\
\hline
\end{tabular}


Table 9 - continued from previous page.

\begin{tabular}{|c|c|c|c|c|}
\hline & \multicolumn{2}{|c|}{ Assignment } & \multicolumn{2}{|c|}{$\underline{\text { Enrollment }}$} \\
\hline & Coefficient & Std.Err. & Coefficient & Std.Err. \\
\hline 1st year before unemployment & -0.008 & $(0.017)$ & 0.071 & $(0.027)$ \\
\hline 2nd year before unemployment & -0.038 & $(0.019) *$ & -0.011 & $(0.030)$ \\
\hline 3rd year before unemployment & -0.008 & $(0.020)$ & 0.004 & $(0.032)$ \\
\hline 4 th year before unemployment & 0.012 & $(0.020)$ & 0.048 & $(0.033)^{*}$ \\
\hline \multirow{2}{*}{\multicolumn{5}{|c|}{ Month of inflow (August) }} \\
\hline & & & & \\
\hline March & 0.015 & $(0.027)$ & -0.042 & $(0.045)$ \\
\hline April & -0.083 & $(0.027)^{* *}$ & -0.119 & $(0.045)^{*}$ \\
\hline May & -0.086 & $(0.027)^{* *}$ & -0.109 & $(0.045)$ \\
\hline June & -0.076 & $(0.028)^{*}$ & -0.061 & $(0.047)$ \\
\hline July & -0.055 & $(0.027) *$ & 0.010 & $(0.045)$ \\
\hline \multicolumn{5}{|l|}{ Region (Carinthia) } \\
\hline Vienna & 1.368 & $(0.035)^{* *}$ & -0.093 & $(0.064)$ \\
\hline Lower Austria & 0.869 & $(0.037)^{* *}$ & -0.614 & $(0.069)^{* *}$ \\
\hline Upper Austria & 0.269 & $(0.039)^{* *}$ & 0.075 & $(0.073) *$ \\
\hline Salzburg & -0.341 & $(0.053)^{* *}$ & -0.184 & $(0.100)$ \\
\hline Tirol & -0.493 & $(0.049)^{* *}$ & -0.073 & $(0.094)$ \\
\hline Vorarlberg & 0.199 & $(0.054)^{* *}$ & -0.151 & $(0.099)$ \\
\hline Burgenland & 0.636 & $(0.054)^{* *}$ & 0.143 & $(0.096)^{* *}$ \\
\hline Styria & 0.471 & $(0.039)^{* *}$ & -0.089 & $(0.071)$ \\
\hline Constant & -1.867 & $(0.118)^{* *}$ & -1.225 & $(0.200)^{* *}$ \\
\hline Observations & 116,361 & & 27,186 & \\
\hline
\end{tabular}

Note: Estimation results from logit models of assignment and enrollment conditional on assignment on individual characteristics. The sample includes all male workers entering unemployment March - August 2001 with a spell of unemployment longer than 1 day and no unemployment during the 30 days prior to this spell, aged 15-65. Average wages are calculated as the average of monthly wages (in Euro, year 2000 prices) in all jobs during the year, and set zero if no wage is reported. 